\title{
Effect of ZnO Facet on Ethanol Steam Reforming over Co/ZnO
}

\author{
Ning Yu ${ }^{1}, \mathrm{He}$ Zhang ${ }^{1}$, Stephen D. Davidson ${ }^{1}$, Junming Sun ${ }^{1 *}$, Yong Wang ${ }^{1,2 *}$ \\ ${ }^{1}$ The Gene and Linda Voiland School of Chemical Engineering and Bioengineering, \\ Washington State University, Pullman, WA 99164, United States \\ ${ }^{2}$ Institute for Integrated Catalysis, Pacific Northwest National Laboratory, Richland, WA \\ 99352, United States
}

*Corresponding authors: junming.sun@wsu.edu, yong.wang@pnnl.gov 


\begin{abstract}
The effects of $\mathrm{ZnO}$ facets on ethanol steam reforming (ESR) were investigated over $\mathrm{Co} / \mathrm{ZnO}$ catalysts synthesized using $\mathrm{ZnO}$ with different fractions of (10-10) nonpolar facet. Co supported on $\mathrm{ZnO}$ with a higher fraction of (10-10) non-polar facet shows higher $\mathrm{C}-\mathrm{C}$ cleavage activity and higher selectivity to $\mathrm{CO}_{2}$ (lower selectivity to $\mathrm{CO}$ ) compared with Co supported on $\mathrm{ZnO}$ with less (10-10) non-polar facet exposed. The improved ethanol steam reforming performances are attributed to the high fraction of metallic Co stabilized by the $\mathrm{ZnO}(10-10)$ non-polar facet, which enhanced C-C cleavage and water-gas-shift (WGS) activities.
\end{abstract}

Key words: ethanol steam reforming; cobalt; ZnO; facet; water gas shift 


\section{Introduction}

Over the last few decades, hydrogen production from ethanol steam reforming (ESR) has been widely studied due to its high hydrogen yield, increased availability and reduced cost of ethanol driven by the technical innovation of ethanol production from diversified biomass feedstock [1-4]. Typically, ESR involves steam reforming, water gas shift (WGS) and methanation reactions [4, 5]. WGS converts $\mathrm{CO}$ and water to $\mathrm{CO}_{2}$ and $\mathrm{H}_{2}$ which will reduce $\mathrm{CO}$ selectivity and increase $\mathrm{H}_{2}$ yield in ESR which is highly desired.

Co based catalysts have been widely studied in ethanol steam reforming due to cobalt's high C-C cleavage activity and low methane selectivity [4, 6-9] Numerous studies have revealed that both the nature of support material and the oxidation state of cobalt have significant effects on reaction pathway and catalyst deactivation [1, 2, 9-14]. It has been found that $\mathrm{Co}^{0}$ has a higher activity for $\mathrm{C}-\mathrm{C}$ cleavage compared to $\mathrm{Co}^{2+}$ and has shown a higher selectivity to $\mathrm{CO}_{2}$; in contrast, $\mathrm{Co}^{2+}$ has shown a higher activity for dehydrogenation of ethanol and a higher selectivity to $\mathrm{CH}_{4}$ due to the methanation of $\mathrm{CO}$ and $\mathrm{CO}_{2}[15]$. A high $\mathrm{Co}^{0} / \mathrm{Co}^{2+}$ ratio is crucial to maintain both $\mathrm{C}-\mathrm{C}$ cleavage and WGS activity [15-18]. On the other hand, while support with high water dissociation and oxygen mobility could be highly efficient to remove $\mathrm{CH}_{\mathrm{x}}{ }^{*} / \mathrm{C}^{*}$ species oxidation, it could also promote the oxidation of cobalt [9]. Therefore, it is desirable to control the surface chemistry of support for favorable water activation while minimizing the oxidation metallic Co to achieve high activity and selectivity in ESR.

There have been numerous studies on $\mathrm{ZnO}$ polar and non-polar facets in ultra-high vacuum (UHV) system using model catalysts $[19,20]$. For example, the growth and stability of cobalt on different $\mathrm{ZnO}$ facets, including $\mathrm{ZnO}(0001 / 000-1)$ polar facets and 
$\mathrm{ZnO}(10-10)$ nonpolar facet, has been studied in UHV using $\mathrm{ZnO}$ single crystal [21-23]. It was found that lattice oxygen on polar $\mathrm{ZnO}(0001)$ and (000-1) facets became active at temperature above $700 \mathrm{~K}$, leading to the oxidation of metallic cobalt to form $\mathrm{CoO}$ [23]. In contrast, metallic cobalt was found to be thermally stable up to $750 \mathrm{~K}$ on $\mathrm{ZnO}$ (1010)[21], indicating different surface chemistry between $\mathrm{ZnO}$ polar and non-polar facet. Utilizing dominant facet $\mathrm{ZnO}$ powder, the effects of $\mathrm{ZnO}$ facet were studied in the $\mathrm{Pd} / \mathrm{ZnO}$ system for methanol steam reforming under realistic reaction conditions [24]. Formation of stable $\beta-\mathrm{PdZn}$ was found more facile on polar $\mathrm{ZnO}(0001)$ facet than on nonpolar (10-10) facet, which led to lower CO selectivity in MSR. To our best knowledge, there are still no studies regarding $\mathrm{ZnO}$ facet effects on ESR over $\mathrm{Co} / \mathrm{ZnO}$ catalyst. In this work we study and demonstrate the importance of $\mathrm{ZnO}$ facet on the ethanol steam reforming reaction over the $\mathrm{Co} / \mathrm{ZnO}$ catalysts.

\section{Experimental}

\subsection{Supports and catalysts preparation}

The details for the synthesis of the supports and catalysts are shown supporting material. Briefly, two types of $\mathrm{ZnO}$ supports ( $\mathrm{ZnO}-\mathrm{N}$ and $\mathrm{ZnO}-\mathrm{S}$ ) with different fractions of (10-10) facet were prepared using the method reported by Wang et al. [25] with some modifications and $2 \mathrm{wt} \% \mathrm{Co} / \mathrm{ZnO}$ catalysts were prepared by incipient wetness impregnation. Cobalt acetate was used as cobalt precursor to avoid the potential damage of the facet on $\mathrm{ZnO}$ [26]. The catalysts were denoted as $2 \mathrm{Co} / \mathrm{ZnO}-\mathrm{N}$ and 2Co/ZnO-S, respectively.

\subsection{Characterization}


Nitrogen sorption measurements were conducted on a Micromeritics TriStar II 3020 physisorption analyzer at $-196{ }^{\circ} \mathrm{C}$ using UHP $\mathrm{N}_{2}$. The specific surface areas of the supports and catalysts were calculated based on the Brunauer-Emmett-Teller (BET) model. Catalysts were degassed at $300^{\circ} \mathrm{C}$ for $1 \mathrm{~h}$ under vacuum before measurements. Temperature-programmed reduction experiments by hydrogen $\left(\mathrm{H}_{2}\right.$-TPR) were performed on a Micromeritics AutoChem II 2920. Prior to the TPR experiment, samples were pretreated at $350^{\circ} \mathrm{C}\left(5^{\circ} \mathrm{C} / \mathrm{min}\right)$ in helium flow $(50 \mathrm{ml} / \mathrm{min})$ for $1 \mathrm{~h}$ and then cooled down to $50{ }^{\circ} \mathrm{C}$. During the $\mathrm{H}_{2}-\mathrm{TPR}$, sample is heated up to $600{ }^{\circ} \mathrm{C}\left(10^{\circ} \mathrm{C} / \mathrm{min}\right)$ in $10 \%$ $\mathrm{H}_{2} / \mathrm{Ar}$ flow $(50 \mathrm{ml} / \mathrm{min})$. The gas flow passed through a cold trap $\left(-10^{\circ} \mathrm{C}\right)$ was monitored with Thermal Conductivity Detector (TCD).

TEM images of the supports and catalysts were taken on a FEI Technai G2 20 Twin equipped with a LaB6 electron source. Samples were dispersed in ethanol via ultrasonic bath, and loaded onto the copper grid with ultrathin lacy carbon film. The diameter and length of $\mathrm{ZnO}$ supports were measured using ImageJ software[27].

XRD spectra were collected using Rigaku Miniflex II in the $2 \theta$ angle between $20^{\circ}$ and $80^{\circ}$, at a step of $0.02^{\circ}$ and dwell time of $2.0 \mathrm{~s}$. Refined XRD spectra were collected from $40^{\circ}$ to $65^{\circ}$ at a step size of $0.02^{\circ}$ with a dwell time of $8.0 \mathrm{~s}$. Before XRD measurements, catalysts were reduced in $50 \mathrm{ml} / \mathrm{min}_{2}$ flow at $400{ }^{\circ} \mathrm{C}$ for 2 hours and passivated in 50 $\mathrm{ml} / \mathrm{min} 0.1 \% \mathrm{O}_{2} / \mathrm{N}_{2}$ flow for 4 hours at room temperature. Cobalt particle size is calculated using Scherer equation.

Diffuse reflectance infrared fouries transform spectra (DRIFTS) were recorded on a Bruker Tenser 27 spectrometer equipped with DRIFT cell. Fine $\mathrm{ZnO}$ powder was filled into the sample holder which is covered by a dome with $\mathrm{ZnSe}$ coated window. ZnO 
samples were first pretreated in flowing UHP helium $(25 \mathrm{ml} / \mathrm{min})$ up to $400{ }^{\circ} \mathrm{C}$ for $10 \mathrm{~min}$ and then in $10 \% \mathrm{O}_{2} / \mathrm{He}(25 \mathrm{ml} / \mathrm{min})$ at $350{ }^{\circ} \mathrm{C}$ for $25 \mathrm{~min}$ to remove surface impurities and physisorbed water species on $\mathrm{ZnO}$. After cooling to $50^{\circ} \mathrm{C}$ in helium, spectra were collected continuously with a spectral resolution of $4 \mathrm{~cm}^{-1}$ and a time resolution of $60 \mathrm{~s}$. $\mathrm{KBr}$ was used as the background.

\subsection{Catalytic test}

Ethanol steam reforming reactions were conducted under atmospheric pressure in a fixed bed quartz tubular reactor (I.D. $6.5 \mathrm{~mm}$ ). $200 \mathrm{mg}$ of $2 \mathrm{wt} \% \mathrm{Co} / \mathrm{ZnO}$ samples diluted with 9 times of inactive SiC (all 150-250 $\mu \mathrm{m}$ ) were loaded and held between two quartz wool layers. A thermal couple was placed at the catalyst bed outside of the tube to monitor the reaction temperature. Before reaction, the catalyst was first reduced under $10 \% \mathrm{H}_{2} / \mathrm{Ar}(50 \mathrm{ml} / \mathrm{min})$ flow for $2 \mathrm{~h}$ at $400{ }^{\circ} \mathrm{C}$. After reduction, $\mathrm{N}_{2}$ flow $(50 \mathrm{ml} / \mathrm{min})$ was used to purge the reactor for $30 \mathrm{~min}$. Ethanol $(\mathrm{EtOH})$ solution (steam to carbon molar ratio of 5) was pumped into a vaporizer at $175^{\circ} \mathrm{C}$ with a rate of $1 \mathrm{ml} / \mathrm{h}$. The vaporized feed was carried into the reactor by $\mathrm{N}_{2}$ flow $(20 \mathrm{ml} / \mathrm{min})$. The EtOH partial pressure $\left(\mathrm{P}_{\mathrm{EtOH}}\right)$ was fixed at $4.2 \mathrm{kPa}$. Effluent gases passed through a cold trap and a Drierite column to remove condensable products and moisture. The dry gases were then sent to an Agilent CP490 microGC equipped with 4 parallel columns and TCDs for analysis. A 5 $\AA ̊$ molecular sieve was used to separate and analyze $\mathrm{H}_{2}, \mathrm{~N}_{2}, \mathrm{CH}_{4}$ and $\mathrm{CO}$. A PPQ column was used to separate and analyze $\mathrm{CO}_{2}, \mathrm{C}_{2} \mathrm{H}_{4}, \mathrm{C}_{2} \mathrm{H}_{6}, \mathrm{C}_{3} \mathrm{H}_{6}$ and $\mathrm{C}_{3} \mathrm{H}_{8}$. $\mathrm{An} \mathrm{Al}_{2} \mathrm{O}_{3}$ column was used to separate and analyze $\mathrm{C}_{3} \mathrm{H}_{6}, \mathrm{C}_{3} \mathrm{H}_{8}$ and $\mathrm{C}_{4} \mathrm{H}_{8}$, any additional hydrocarbons would appear on this column as well. Reaction was carried out at atmospheric pressure. 
Dry gas conversion was calculated with equation $1 . " n "$ is the number of carbon atoms in gas products $\mathrm{C}_{n}$.

Dry gas conversion $(\%)=\frac{\sum n \cdot \text { molar flow rate of } \mathrm{C}_{n} \text { products }}{2 \cdot \text { molar feed rate of } \mathrm{EtOH}} \times 100$

Equation 2 was used to calculate selectivity to $\mathrm{C}_{1}$ products.

$$
\mathrm{C}_{1} \text { selectivity }(\%)=\frac{\text { molar flow rate of } \mathrm{C}_{1} \text { product }}{\Sigma \text { molar flow rate of } \mathrm{C}_{1} \text { products }} \times 100
$$

Equation 3 was used to calculate $\mathrm{C}-\mathrm{C}$ cleavage of ethanol.

$$
\mathrm{C}-\mathrm{C} \text { cleavage }(\%)=\frac{\Sigma \text { molar flow rate of } \mathrm{C}_{1} \text { products }}{2 \cdot \text { molar feed rate of } \mathrm{EtOH}} \times 100
$$

\section{Results and Discussion}

\subsection{Characterization of support and catalysts}

The textural properties of $\mathrm{ZnO}$ supports and $\mathrm{Co} / \mathrm{ZnO}$ catalysts are shown in Table 1. $\mathrm{ZnO}-\mathrm{N}$ has a surface area of $37 \mathrm{~m}^{2} / \mathrm{g}$, and the surface area of $\mathrm{ZnO}-\mathrm{S}$ is $7 \mathrm{~m}^{2} / \mathrm{g}$. The decreased surface area suggests that the high calcinations temperature (i.e., $550{ }^{\circ} \mathrm{C}$ ) changed the morphology of $\mathrm{ZnO}-\mathrm{N}$, which can be further confirmed by the TEM observation discussed below. After adding Co to $\mathrm{ZnO}-\mathrm{N}$ support, the surface area of $2 \mathrm{Co} / \mathrm{ZnO}-\mathrm{N}$ decreased slightly from 37 to $34 \mathrm{~m}^{2} / \mathrm{g}$. The decreased surface area is likely due to the minor change of the morphology of the $\mathrm{ZnO}-\mathrm{N}$ support which will be further discussed in the following part. The surface area of $2 \mathrm{Co} / \mathrm{ZnO}-\mathrm{S}$, in contrast, increased from 7 to $12 \mathrm{~m}^{2} / \mathrm{g}$.

TEM images of $\mathrm{ZnO}-\mathrm{N}, \mathrm{ZnO}-\mathrm{S}, 2 \mathrm{Co} / \mathrm{ZnO}-\mathrm{N}$ and 2Co/ZnO-S are shown in Fig. 1. Images of samples were used to estimate the fraction of $\mathrm{ZnO}(10-10)$ facet. TEM of ZnO-N shows a long needle-shape morphology with a diameter around 10 20 nm (Fig. 1a). The estimated (10-10) fraction is $~ 93 \%$ (Table 1). Consistent with the decreased 
surface area, TEM (Fig. S2) and SEM (Fig. S3) of ZnO-S reveal that its morphology changed significantly from long needle to irregular shaped particles with diameter of $50 \sim 100 \mathrm{~nm}$, which makes the determination of the fraction of the (10-10) facet difficult. It was found that surface hydroxyl groups on the $\mathrm{ZnO}(10-10)$ and $\mathrm{ZnO}(000-1)$ facet showed different band frequencies [28]. Here, DRIFTS was further conducted to differentiate the different facet on the $\mathrm{ZnO}-\mathrm{N}$ and $\mathrm{ZnO}-\mathrm{S}$ supports, as shown in Fig. 2. While the bands at $3680,3659(3639) \mathrm{cm}^{-1}$ are related to the hydroxyl group on $\mathrm{ZnO}$ (10-10) facet, the one at $3618 \mathrm{~cm}^{-1}$ is attributed to the hydroxyl groups on $\mathrm{ZnO}(000-1)$ facet [28]. The peaks at 3558 and $3446 \mathrm{~cm}^{-1}$ are related to the interaction of water with oxygen defects forms $\mathrm{O}-\mathrm{H}^{\cdots} \mathrm{O}$ species. It is clear that the intensity of bands at 3680 and $3659 \mathrm{~cm}^{-1}$ are much stronger on $\mathrm{ZnO}-\mathrm{N}$ than on $\mathrm{ZnO}-\mathrm{S}$. It suggests a higher fraction of (10-10) facet on $\mathrm{ZnO}-\mathrm{N}$ than on $\mathrm{ZnO}-\mathrm{S}$, consistent with the TEM observations. It is interesting to note that the band at $3558 \mathrm{~cm}^{-1}$ on $\mathrm{ZnO}-\mathrm{N}$ is also much stronger than that on $\mathrm{ZnO}-\mathrm{S}$, indicating that $\mathrm{O}-\mathrm{H} \cdots \mathrm{O}$ species might also be related to the $(10-10)$ facet. Upon addition of cobalt, it was found that the length of the needle-like $\mathrm{ZnO}$ ( $\mathrm{ZnO}-\mathrm{N})$ became shorter and the diameter also increases slightly (Fig. 1c). However, the needlelike shape is still conserved with $\sim 89 \%(10-10)$. On the other hand, the morphology of ZnO-S showed little change (Fig. 1d). From TEM, the average cobalt particle sizes of 2Co/ZnO-N and 2Co/ZnO-S catalysts were very close which were $6.7 \mathrm{~nm}$ and $7.6 \mathrm{~nm}$, respectively.

Fig. 3 shows the XRD patterns of $\mathrm{Co} / \mathrm{ZnO}$ catalysts. A broad and weak diffraction peak at $2 \theta$ of $44^{\circ}$, characteristic of metallic Co peaks, were identified. The average cobalt particle sizes were calculated using Scherrer equation (Table 1). Both $2 \mathrm{Co} / \mathrm{ZnO}-\mathrm{N}$ and 
$2 \mathrm{Co} / \mathrm{ZnO}-\mathrm{S}$ catalyst have a similar average cobalt particle size of $4.4 \mathrm{~nm}$ and $5.5 \mathrm{~nm}$, which are smaller compared with TEM observation due to possible peak broadening caused by multiple factors such as instrumental effects, and micro-stresses[29]. However, both techniques suggest the particle size on the two supports was similar. $\mathrm{H}_{2}$-TPR was further studied to compare the reducibility properties of $2 \mathrm{Co} / \mathrm{ZnO}-\mathrm{N}$ and 2Co/ZnO-S as shown in Fig.4. For 2Co/ZnO-S catalyst (Fig. 4 a), two major hydrogen consumption peaks were detected at $240^{\circ} \mathrm{C}$ and $410^{\circ} \mathrm{C}$, which can be ascribed to cobalt reduction from $\mathrm{Co}^{3+}$ to $\mathrm{Co}^{2+}$ and $\mathrm{Co}^{2+}$ to metallic $\mathrm{Co}$, respectively [7]. Moreover, separate $\mathrm{H}_{2}$ TPR experiments over both $\mathrm{ZnO}$ ( Fig.S4) and 5 wt\% Co/ZnO (Fig. S5) were also conducted to confirm the peak assignment. Over $2 \mathrm{Co} / \mathrm{ZnO}-\mathrm{N}$, a similar reduction peak for $\mathrm{Co}^{3+}$ to $\mathrm{Co}^{2+}$ was also observed at $240{ }^{\circ} \mathrm{C}$. Unlike $2 \mathrm{Co} / \mathrm{ZnO}-\mathrm{S}$, $2 \mathrm{Co} / \mathrm{ZnO}-\mathrm{N}$ showed two reduction peaks at higher temperature, $370{ }^{\circ} \mathrm{C}$ and $440^{\circ} \mathrm{C}$, both of which are attributed to the reduction of $\mathrm{Co}^{2+}$ to metallic Co. The peak at $370^{\circ} \mathrm{C}$ could be related to the reduction of $\mathrm{Co}^{2+}$ species that have less interaction with $\mathrm{ZnO}$ (10-10) surface. The peak at $440{ }^{\circ} \mathrm{C}$ was attributed to the reduction of cobalt that strongly interacted with $\mathrm{ZnO}$ polar surface as suggested by the work of Hyman et al. [23] Assuming the high-temperature reduction peak is due to the reduction of $\mathrm{Co}^{2+}$, a further quantification of hydrogen consumption reveals that the reduction extent of $\mathrm{Co}^{2+}$ on $2 \mathrm{Co} / \mathrm{ZnO}-\mathrm{N}$ and $2 \mathrm{Co} / \mathrm{ZnO}-\mathrm{S}$ are $64 \%$ and $62 \%$, respectively. It indicates that there are still irreducible $\mathrm{Co}^{2+}$ species on $\mathrm{ZnO}$, likely due to the strong metal-support interaction. In addition, the formation of two types of $\mathrm{Co}^{2+}$ species with different reducibility indicates a unique surface chemistry of the (10-10) non-polar facet, which will be further addressed in the following ESR reactions. 


\subsection{Ethanol steam reforming}

Under the conditions studied for ethanol steam reforming deactivation of catalysts was observed. To best investigate the effects of $\mathrm{ZnO}(10-10)$ facet on ethanol steam reforming over $\mathrm{Co} / \mathrm{ZnO}$ catalysts the initial catalyst activity was primarily investigated; experimental data collected and averaged within 30 minutes of time-on-stream was used to compare the activity and selectivity with the minimal influence of catalyst deactivation. Reactions were performed at $400{ }^{\circ} \mathrm{C}$ where it is found that $\mathrm{ZnO}-\mathrm{N}$ support exhibited a relatively high stability [24].

Prior to the catalyst test on $\mathrm{Co} / \mathrm{ZnO}$, the performance of $\mathrm{ZnO}-\mathrm{N}$ and $\mathrm{ZnO}-\mathrm{S}$ supports were tested in ethanol steam reforming reaction as $\mathrm{ZnO}$ was also found active for ethanol steam reforming [30]. Under the current reaction conditions, however, both ZnO-N and $\mathrm{ZnO}-\mathrm{S}$ supports showed no detectable $\mathrm{C} 1$ products suggesting negligible steam reforming activity. This could be due to the different reaction conditions employed in the two cases (i.e., lower $\mathrm{S} / \mathrm{C}$ ratio and much higher ethanol partial pressure and space velocity than that reported [30]). Over $\mathrm{Co} / \mathrm{ZnO}$, selectivity and yield to $\mathrm{CO}_{2}$ were compared and shown in Fig. 5. Under the identical reaction conditions, C1 products including $\mathrm{CO}_{2}, \mathrm{CO}$ and $\mathrm{CH}_{4}$ were the most significant products and less than $1 \%$ selectivity to $\mathrm{C} 2$ and $\mathrm{C} 3$ products were observed. 2Co/ZnO-N catalyst showed a much higher activity than $2 \mathrm{Co} / \mathrm{ZnO}-\mathrm{S}$ in terms of $\mathrm{C}-\mathrm{C}$ bond cleavage (49.7\% vs. $33.5 \%)$ with similar cobalt particle sizes. In addition, selectivity to $\mathrm{CO}_{2}$ on $2 \mathrm{Co} / \mathrm{ZnO}-\mathrm{N}$ catalyst was also higher than over $2 \mathrm{Co} / \mathrm{ZnO}-\mathrm{S}$ catalyst (68.0\% vs. $49.7 \%)$. CO selectivity on $2 \mathrm{Co} / \mathrm{ZnO}-\mathrm{N}$ catalyst was significantly lower than that of $2 \mathrm{Co} / \mathrm{ZnO}-\mathrm{S}$ catalyst $(22.5 \%$ vs. 40.6\%). However, methane selectivity between the two catalysts did not show much 
difference. The large difference in $\mathrm{CO}$ selectivity and small difference in $\mathrm{CH}_{4}$ selectivity suggested that the higher selectivity to $\mathrm{CO}_{2}$ is due to an enhanced WGS activity on 2Co/ZnO-N catalysts, converting $\mathrm{CO}$ into $\mathrm{CO}_{2}$.

Previous studies have shown that Co particle size plays an important role in water dissociation and thus $\mathrm{CO}$ oxidation to $\mathrm{CO}_{2}$ [31]. However, both TEM and XRD suggest that $2 \mathrm{Co} / \mathrm{ZnO}-\mathrm{N}$ and $2 \mathrm{Co} / \mathrm{ZnO}-\mathrm{S}$ catalysts have similar cobalt particle size. The complication introduced by Co particle size can be thus excluded. Karim et al. investigated effects of $\mathrm{Co}^{0} / \mathrm{Co}^{2+}$ on ethanol steam reforming over $\mathrm{Co} / \mathrm{MgO}$ catalysts finding that $\mathrm{Co}^{0}$ was much more active than $\mathrm{Co}^{2+}$ for ethanol conversion, $\mathrm{C}-\mathrm{C}$ cleavage, and WGS reaction, while $\mathrm{Co}^{2+}$ promoted methanation of $\mathrm{CO}$ and $\mathrm{CO}_{2}$ to $\mathrm{CH}_{4}$ [15]. More importantly, recent UHV study of cobalt deposited on $\mathrm{ZnO}$ single crystal suggest that metallic cobalt nanoparticles are more resistant to oxidation on $\mathrm{ZnO}(10-10)$ nonpolar facet due to the less reducible nature of the facet [21]. It is thus hypothesized that the high $\mathrm{C}-\mathrm{C}$ bond cleavage on $2 \mathrm{Co} / \mathrm{ZnO}-\mathrm{N}$ catalyst and high yield to $\mathrm{CO}_{2}$ could be due to a higher fraction of metallic Co maintained on the $\mathrm{ZnO}$ nonpolar facet during ESR.

\section{Conclusions}

The effects of $\mathrm{ZnO}$ facet on ethanol steam reforming were investigated over $\mathrm{Co} / \mathrm{ZnO}$ catalysts. Cobalt nanoparticles of similar particle size were prepared on $\mathrm{ZnO}-\mathrm{N}$ and ZnO-S supports with different percentages of $\mathrm{ZnO}$ (10-10) facet exposed. Under similar reaction conditions, $\mathrm{Co} / \mathrm{ZnO}-\mathrm{N}$ catalyst with a higher fraction of $\mathrm{ZnO}(10-10)$ facet exhibited a higher $\mathrm{C}-\mathrm{C}$ cleavage activity compared to the $\mathrm{Co} / \mathrm{ZnO}-\mathrm{S}$ catalyst. Moreover, higher $\mathrm{CO}_{2}$ selectivity and lower $\mathrm{CO}$ selectivity were also observed on $\mathrm{Co} / \mathrm{ZnO}-\mathrm{N}$. This phenomenon can be related to the high fraction of metallic Co maintained on the $\mathrm{ZnO}$ 
(10-10) facet in ESR over the 2Co/ZnO-N catalyst. For the first time, the present study demonstrated that $\mathrm{ZnO}(10-10)$ can prevent metallic cobalt from oxidation in realistic $\mathrm{Co} / \mathrm{ZnO}$ catalyst, evidenced by the favorable $\mathrm{C}-\mathrm{C}$ cleavage and WGS reactions in ethanol steam reforming. The finding of the unique property of $\mathrm{ZnO}(10-10)$ could direct rational design of catalysts for ethanol steam reforming reactions.

\section{Acknowledgement}

We acknowledge the US Department of Energy, Office of Basic Energy Sciences for the financial support, the WSU Franceschi Microscopy Center and Dr. Knoblauch for the use of the TEM and Zizwe Chase for the use of XRD. J. S. acknowledges the New Faculty Seed Grant support from Washington State University.

\section{Reference}

[1] J. Llorca, N. Homs, J. Sales, P.R. de la Piscina, Efficient production of hydrogen over supported cobalt catalysts from ethanol steam reforming, J Catal, 209 (2002) 306317.

[2] M.S. Batista, R.K.S. Santos, E.M. Assaf, J.M. Assaf, E.A. Ticianelli, High efficiency steam reforming of ethanol by cobalt-based catalysts, J Power Sources, 134 (2004) 2732.

[3] A.N. Fatsikostas, D.I. Kondarides, X.E. Verykios, Production of hydrogen for fuel cells by reformation of biomass-derived ethanol, Catal Today, 75 (2002) 145-155. [4] A. Haryanto, S. Fernando, N. Murali, S. Adhikari, Current status of hydrogen production techniques by steam reforming of ethanol: A review, Energ Fuel, 19 (2005) 2098-2106.

[5] S.M. de Lima, A.M. da Silva, L.O.O. da Costa, U.M. Graham, G. Jacobs, B.H. Davis, L.V. Mattos, F.B. Noronha, Study of catalyst deactivation and reaction mechanism of steam reforming, partial oxidation, and oxidative steam reforming of ethanol over $\mathrm{Co} / \mathrm{CeO} 2$ catalyst, J Catal, 268 (2009) 268-281.

[6] C.K.S. Choong, Z.Y. Zhong, L. Huang, Z. Wang, T.P. Ang, A. Borgna, J.Y. Lin, L. Hong, L.W. Chen, Effect of calcium addition on catalytic ethanol steam reforming of $\mathrm{Ni} / \mathrm{Al}$ 2O3: I. Catalytic stability, electronic properties and coking mechanism, Appl Catal a-Gen, 407 (2011) 145-154.

[7] J.F. Da Costa-Serra, R. Guil-Lopez, A. Chica, Co/ZnO and Ni/ZnO catalysts for hydrogen production by bioethanol steam reforming. Influence of $\mathrm{ZnO}$ support morphology on the catalytic properties of $\mathrm{Co}$ and $\mathrm{Ni}$ active phases, Int $\mathrm{J}$ Hydrogen Energ, 35 (2010) 6709-6716. 
[8] M.C. Sanchez-Sanchez, R.M. Navarro, J.L.G. Fierro, Ethanol steam reforming over $\mathrm{Ni} / \mathrm{MxOy}-\mathrm{Al} 2 \mathrm{O} 3$ ( $\mathrm{M}=\mathrm{Ce}$, $\mathrm{La}, \mathrm{Zr}$ and $\mathrm{Mg}$ ) catalysts: Influence of support on the hydrogen production, Int J Hydrogen Energ, 32 (2007) 1462-1471.

[9] S.D. Davidson, H. Zhang, J.M. Sun, Y. Wang, Supported metal catalysts for alcohol/sugar alcohol steam reforming, Dalton Trans., 43 (2014) 11782-11802. [10] B. Banach, A. Machocki, P. Rybak, A. Denis, W. Grzegorczyk, W. Gac, Selective production of hydrogen by steam reforming of bio-ethanol, Catal Today, 176 (2011) 2835.

[11] F. Haga, T. Nakajima, H. Miya, S. Mishima, Catalytic properties of supported cobalt catalysts for steam reforming of ethanol, Catal Lett, 48 (1997) 223-227.

[12] H. Song, B. Mirkelamoglu, U.S. Ozkan, Effect of cobalt precursor on the performance of ceria-supported cobalt catalysts for ethanol steam reforming, Appl Catal a-Gen, 382 (2010) 58-64.

[13] H. Song, L.Z. Zhang, R.B. Watson, D. Braden, U.S. Ozkan, Investigation of bioethanol steam reforming over cobalt-based catalysts, Catal Today, 129 (2007) 346-354. [14] L.V. Mattos, G. Jacobs, B.H. Davis, F.B. Noronha, Production of Hydrogen from Ethanol: Review of Reaction Mechanism and Catalyst Deactivation, Chem. Rev., 112 (2012) 4094-4123.

[15] A.M. Karim, Y. Su, M.H. Engelhard, D.L. King, Y. Wang, Catalytic Roles of Co-0 and $\mathrm{Co} 2+$ during Steam Reforming of Ethanol on Co/MgO Catalysts, Acs Catal, 1 (2011) 279-286.

[16] V.M. Lebarbier, A.M. Karim, M.H. Engelhard, Y. Wu, B.Q. Xu, E.J. Petersen, A.K. Datye, Y. Wang, The Effect of Zinc Addition on the Oxidation State of Cobalt in Co/ZrO2 Catalysts, Chemsuschem, 4 (2011) 1679-1684.

[17] S.D. Davidson, J.M. Sun, Y. Wang, Ethanol Steam Reforming on Co/CeO2: The Effect of ZnO Promoter, Top Catal, 56 (2013) 1651-1659.

[18] S.D. Davidson, J.M. Sun, Y.C. Hong, A.M. Karim, A.K. Datye, Y. Wang, The effect of $\mathrm{ZnO}$ addition on $\mathrm{Co} / \mathrm{C}$ catalyst for vapor and aqueous phase reforming of ethanol, Catal Today, 233 (2014) 38-45.

[19] E. Martono, M.P. Hyman, J.M. Vohs, Reaction pathways for ethanol on model Co/ZnO(0001) catalysts, Phys Chem Chem Phys, 13 (2011) 9880-9886.

[20] G. Kwak, K.J. Yong, Adsorption and reaction of ethanol on ZnO nanowires, J Phys Chem C, 112 (2008) 3036-3041.

[21] S.H. Su, H.H. Chen, T.H. Lee, Y.J. Hsu, J.C.A. Huang, Thermally Activated Interaction of Co Growth with ZnO(10(1)over-bar0) Surface, J Phys Chem C, 117 (2013) $17540-17547$.

[22] J.A. Dumont, M.C. Mugumaoderha, J. Ghijsen, S. Thiess, W. Drube, B. Walz, M. Tolkiehn, D. Novikov, F.M.F. de Groot, R. Sporken, Thermally Activated Processes at the $\mathrm{Co} / \mathrm{ZnO}$ Interface Elucidated Using High Energy X-rays, J Phys Chem C, 115 (2011) 7411-7418.

[23] M.P. Hyman, E. Martono, J.M. Vohs, Studies of the Structure and Interfacial Chemistry of Co Layers on ZnO(0001), J Phys Chem C, 114 (2010) 16892-16899. [24] H. Zhang, J.M. Sun, V.L. Dagle, B. Halevi, A.K. Datye, Y. Wang, Influence of ZnO Facets on Pd/ZnO Catalysts for Methanol Steam Reforming, Acs Catal, 4 (2014) 23792386. 
[25] C.L. Wang, E.H. Shen, E.B. Wang, L. Gao, Z.K. Kang, C.G. Tian, Y. Lan, C. Zhang, Controllable synthesis of $\mathrm{ZnO}$ nanocrystals via a surfactant-assisted alcohol thermal process at a low temperature, Mater Lett, 59 (2005) 2867-2871.

[26] A.M. Karim, T. Conant, A.K. Datye, Controlling ZnO morphology for improved methanol steam reforming reactivity, Phys. Chem. Chem. Phys., 10 (2008) 5584-5590. [27] C.A. Schneider, W.S. Rasband, K.W. Eliceiri, NIH Image to ImageJ: 25 years of image analysis, Nature Methods, 9 (2012) 671-675.

[28] H. Noei, H.S. Qiu, Y.M. Wang, E. Loffler, C. Woll, M. Muhler, The identification of hydroxyl groups on ZnO nanoparticles by infrared spectroscopy, Phys. Chem. Chem. Phys., 10 (2008) 7092-7097.

[29] T. Ungar, Micro structural parameters from X-ray diffraction peak broadening, Scripta Mater, 51 (2004) 777-781.

[30] J. Llorca, P.R. de la Piscina, J. Sales, N. Homs, Direct production of hydrogen from ethanolic aqueous solutions over oxide catalysts, Chem Commun, (2001) 641-642. [31] J.M. Sun, D.H. Mei, A.M. Karim, A.K. Datye, Y. Wang, Minimizing the Formation of Coke and Methane on Co Nanoparticles in Steam Reforming of Biomass-Derived Oxygenates, Chemcatchem, 5 (2013) 1299-1303. 
Table 1. Textural properties of $\mathrm{ZnO}$ supports and $\mathrm{Co} / \mathrm{ZnO}$ catalysts.

Fig.1. TEM images of (a) ZnO-N, (b) ZnO-S, (c) 2Co/ZnO-N and (d) 2Co/ZnO-S reduced and passivated.

Fig. 2. DRIFT spectra of $\mathrm{ZnO}-\mathrm{N}(\mathrm{a})$ and $\mathrm{ZnO}-\mathrm{S}(\mathrm{b})$.

Fig. 3. XRD patterns of different $\mathrm{Co} / \mathrm{ZnO}$ catalysts: 2Co/ZnO-N (a); 2Co/ZnO-S (b).

Fig. $4 \mathrm{H}_{2}$-TPR profile of 2Co/ZnO-S catalyst (a) and 2Co/ZnO-N catalyst (b).

Fig. 5. Comparison of $\mathrm{CO}_{2}$ selectivity and yield between $2 \mathrm{Co} / \mathrm{ZnO}-\mathrm{N}$ and $2 \mathrm{Co} / \mathrm{ZnO}-\mathrm{S}$.

$200 \mathrm{mg}$ catalysts diluted with 9 times of $\mathrm{SiC}, \mathrm{S} / \mathrm{C}=5: 1, \mathrm{~W} / \mathrm{F}=0.32 \mathrm{~g} \mathrm{~s} \mathrm{ml}^{-1}, \mathrm{P}_{\mathrm{EtOH}}=4.2 \mathrm{kPa}$, $400{ }^{\circ} \mathrm{C}$. 
Table 1. Textural properties of $\mathrm{ZnO}$ supports and $\mathrm{Co} / \mathrm{ZnO}$ catalysts.

\begin{tabular}{|c|c|c|c|c|}
\hline Sample name & $\begin{array}{c}\text { BET surface } \\
\text { area }\left(\mathrm{m}^{2} / \mathrm{g}\right)\end{array}$ & $\begin{array}{c}\text { Fraction of } \\
\mathrm{ZnO}(10-10) \\
\text { facet }(\%)^{\mathrm{c}}\end{array}$ & $\begin{array}{c}\text { Co particle } \\
\text { size }(\mathrm{nm})^{\mathrm{a}}\end{array}$ & $\begin{array}{c}\text { Co particle } \\
\text { size }(\mathrm{nm})^{\mathrm{b}}\end{array}$ \\
\hline ZnO-N & 37 & $93 \pm 5$ & - & - \\
\hline ZnO-S & 7 & - & - & - \\
\hline 2Co/ZnO-N & 34 & $89 \pm 5$ & 6.7 & 4.4 \\
\hline 2Co/ZnO-S & 12 & - & 7.6 & 5.5 \\
\hline
\end{tabular}

${ }^{a}$ Cobalt particle size based on TEM images; ${ }^{b}$ Cobalt particle size from XRD; $c$ the fraction of facet was estimated by assuming a hexagonal prism morphology of the $\mathrm{ZnO}-\mathrm{N}$ support albeit their different dimensions. 

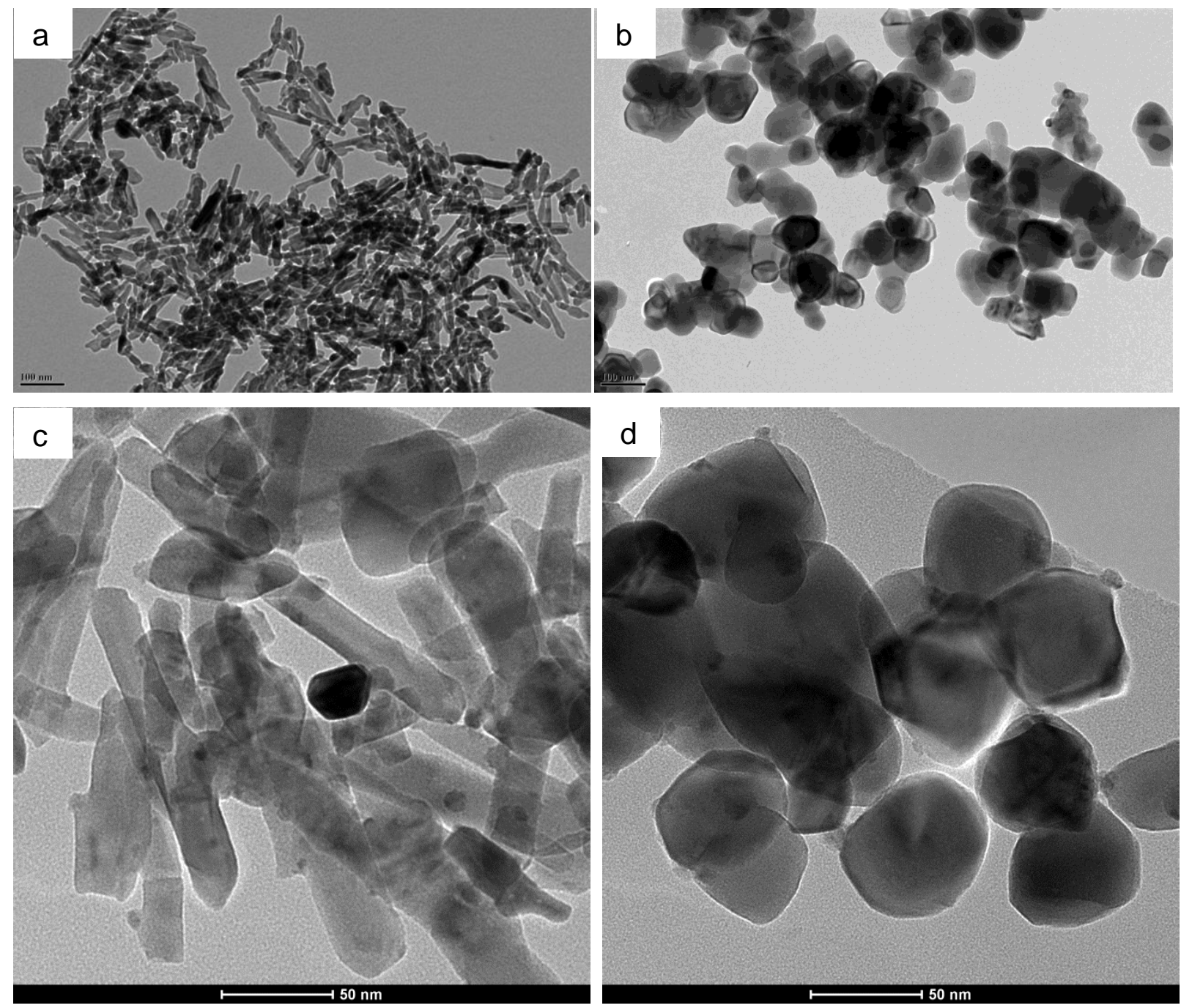

Fig.1. TEM images of (a), ZnO-N; (b), ZnO-S; (c), 2Co/ZnO-N; (d), 2Co/ZnO-S reduced and passivated. 


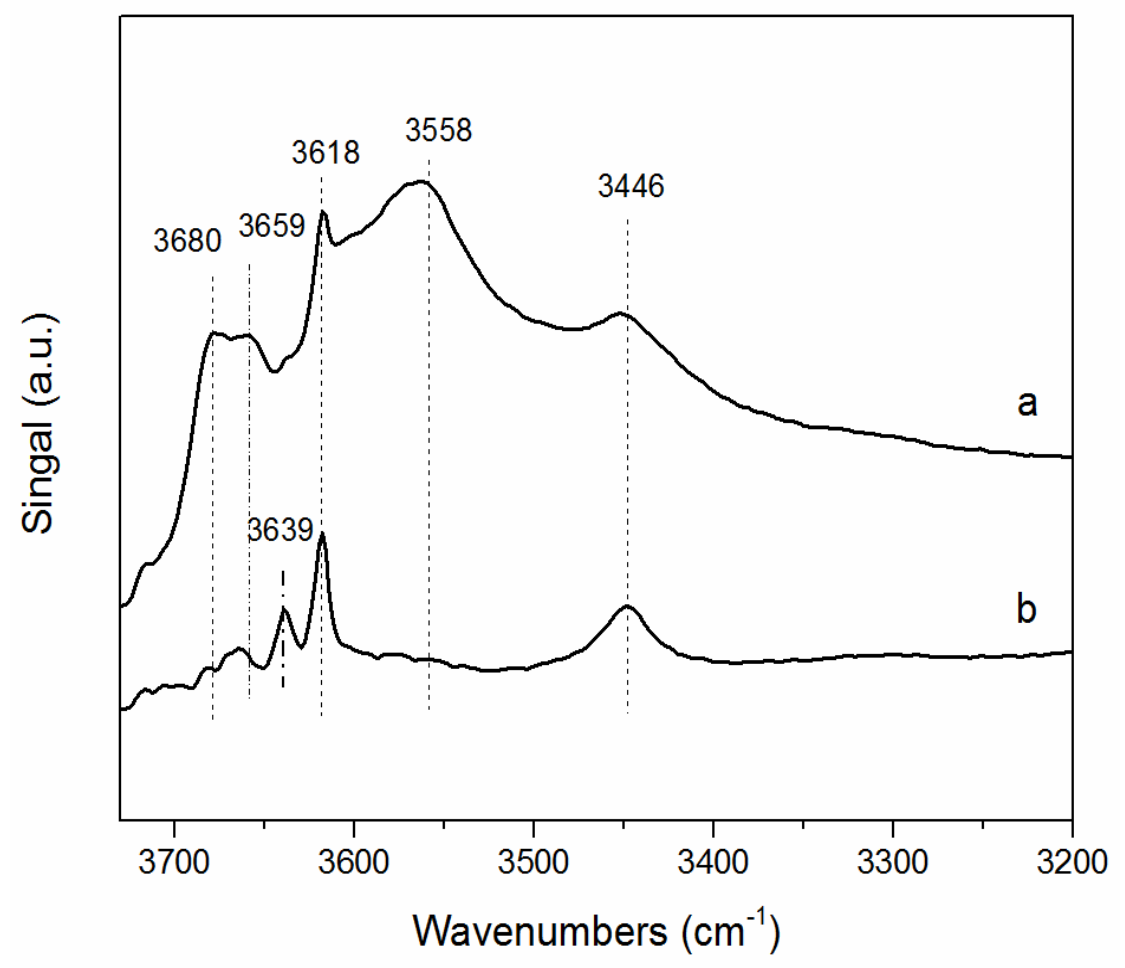

Fig. 2. DRIFT spectra of $\mathrm{ZnO}-\mathrm{N}(\mathrm{a})$ and $\mathrm{ZnO}-\mathrm{S}(\mathrm{b})$. 


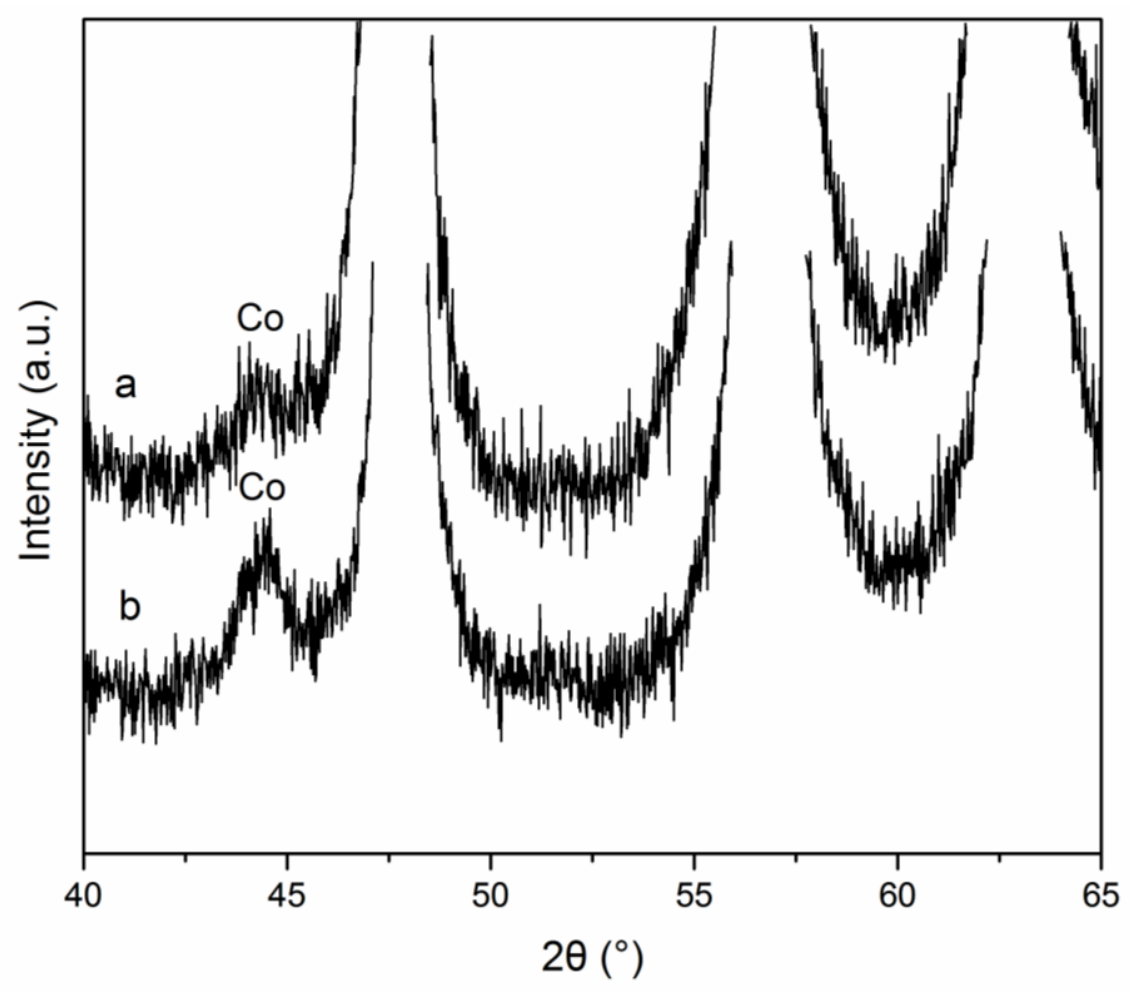

Fig. 3. XRD patterns of (a), 2Co/ZnO-N; (b), 2Co/ZnO-S. 


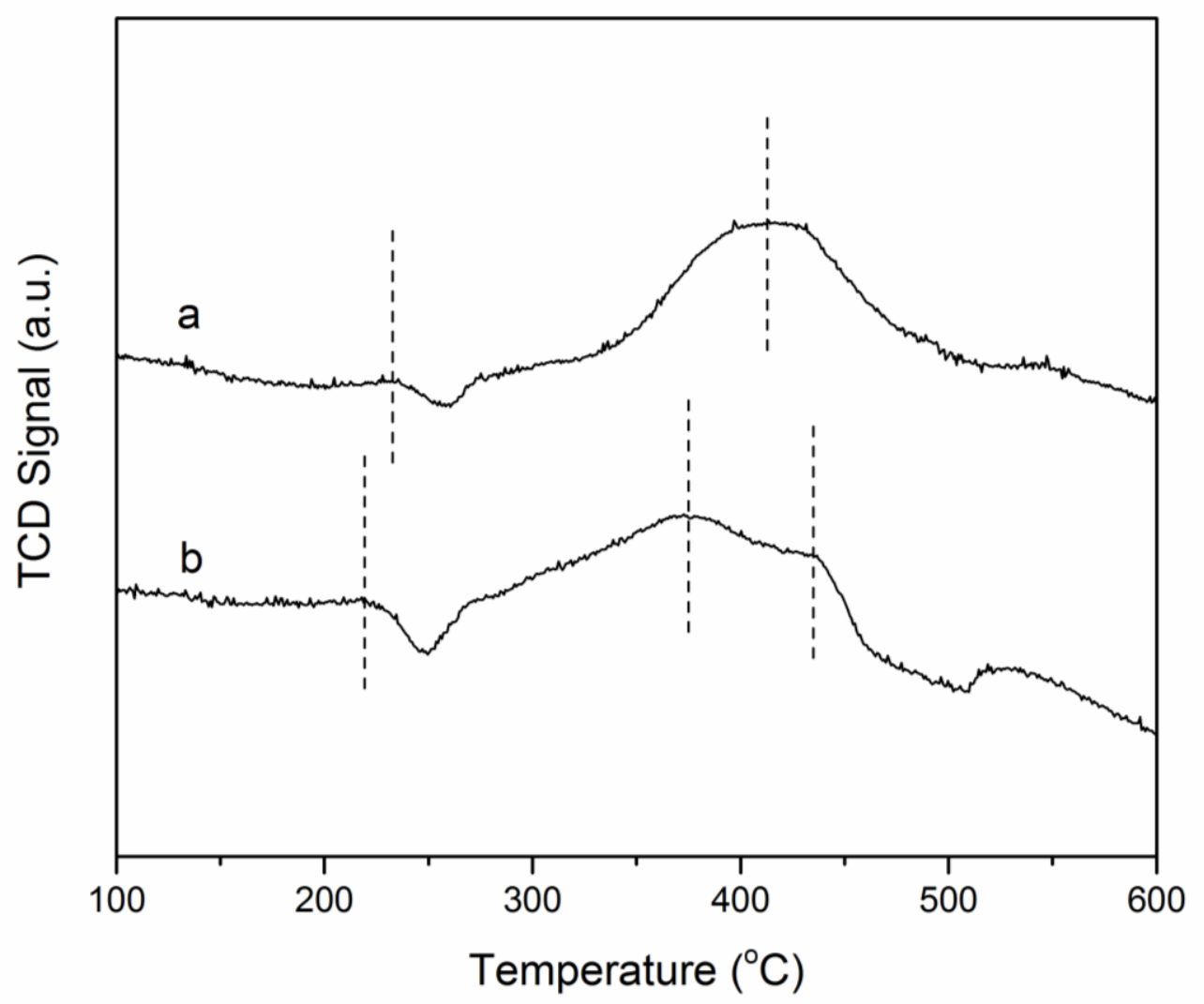

Fig. 4. $\mathrm{H}_{2}$-TPR profile of $2 \mathrm{Co} / \mathrm{ZnO}-\mathrm{S}$ (a) catalyst and $2 \mathrm{Co} / \mathrm{ZnO}-\mathrm{N}$ (b) catalyst. 


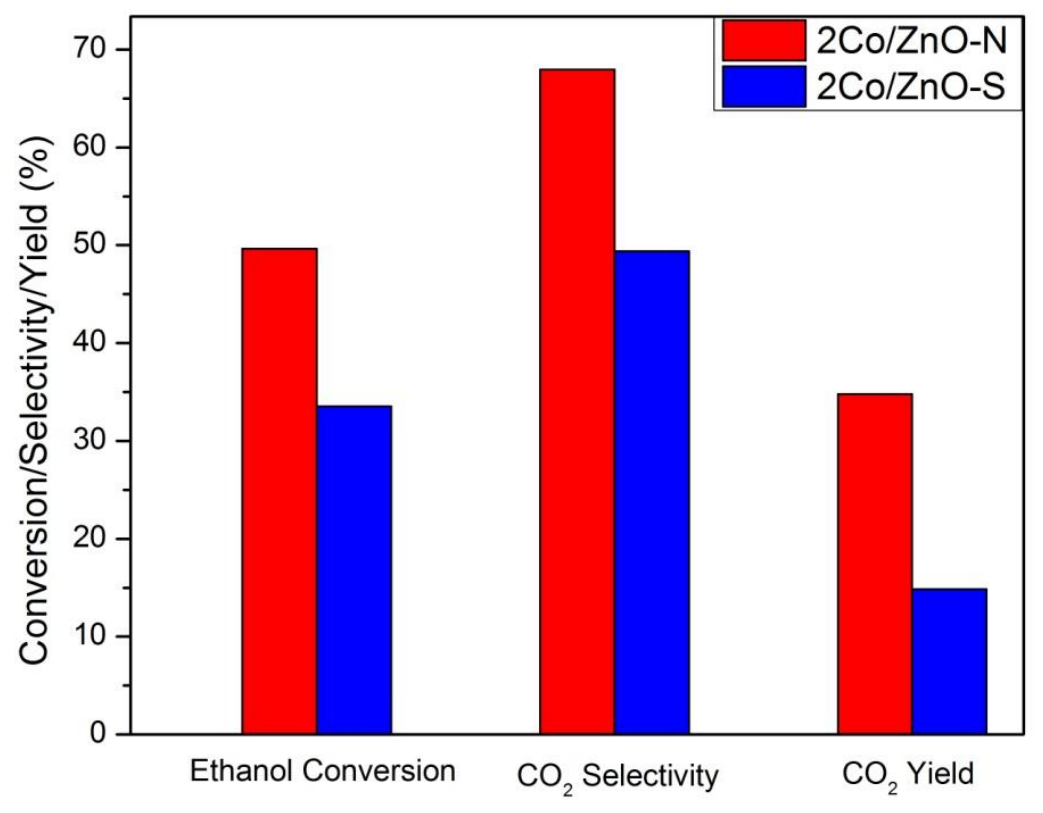

Fig. 5. Comparison of $\mathrm{CO}_{2}$ selectivity and yield over $2 \mathrm{Co} / \mathrm{ZnO}-\mathrm{N}$ and $2 \mathrm{Co} / \mathrm{ZnO}-\mathrm{S}$. $200 \mathrm{mg}$ catalysts diluted with 9 times of $\mathrm{SiC}, \mathrm{S} / \mathrm{C}=5: 1, \mathrm{~W} / \mathrm{F}=0.32 \mathrm{~g} \mathrm{~s} \mathrm{ml}^{-1}, \mathrm{P}_{\mathrm{EtOH}}=4.2 \mathrm{kPa}$, $400^{\circ} \mathrm{C}$. 

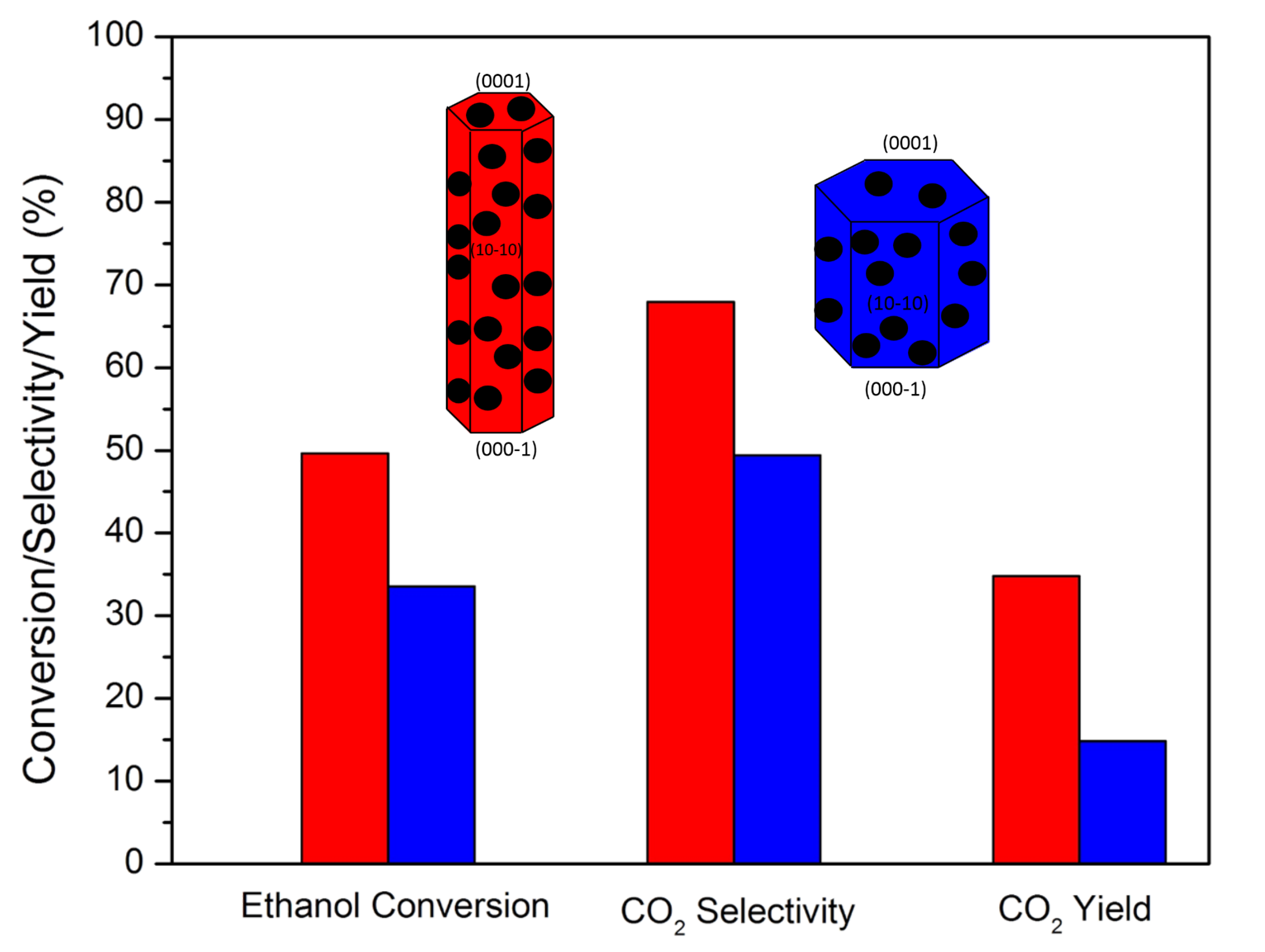